\title{
Aproximación A la literatura oral: LA LEYENDA ENTRE EL MITO, EL CUENTO, LA FANTASÍA Y LAS CREENCIAS
}

\author{
Consuelo Hernández Carrasco
}

Filóloga

La autora ${ }^{1}$, Pascuala Morote Magán, natural de Jumilla, de reconocido prestigio intelectual, es doctora en Filología Románica por la Universidad de Murcia y catedrática de Lengua y Literatura españolas, adscrita al Departamento de Didáctica de la Lengua y la Literatura en la Universidad de Valencia, en la cual ha ejercido su labor docente e investigadora. Es también académica de la Real Academia Alfonso X el Sabio de Murcia. Su currículo está surtido de numerosos trabajos: artículos, libros, cursos de doctorado, dirección de tesis y conferencias, dentro y fuera de España. Todo ello avala su gran formación y experiencia como especialista en el tema tratado en el presente libro: la literatura de transmisión oral.

Observo en el contenido del libro dos perfiles muy diferenciados: uno, el científico, con una tesis y una estructura claramente definidas, un proceso metodológico impecable, un aporte de material riquísimo, objetivos y conclusiones; otro, el humanista, que se basa en las muestras, interesantes y curiosísimas muestras de literatura oral, recopiladas en los trabajos de campo y directamente transmitidas de boca de los informantes a través de numerosas entrevistas. En ellas, el factor humano, la voz, gestualidad, la dicción particular o idiolecto de cada persona entrevistada confieren al trabajo la cercanía y la afectividad que supone el contacto personal directo. Todo ello ubicado en el lugar idóneo, creándose un clima de confianza y calidez para que la comunicación del emisor al receptor sea adecuada, como si se tratase de una performance artística.

Ambos perfiles, científico y humano, encajan perfectamente con la personalidad de la autora porque en ella se dan la mano la ciencia y la humanidad y como tal lo refleja en el rigor y amor que pone en todos sus trabajos.

La tesis concreta planteada en el libro consiste en destacar que, junto a la literatura culta (escrita, inalterable y de autor conocido), de forma paralela discurre

\footnotetext{
${ }^{1}$ Aproximación a la literatura oral: la leyenda entre el mito, el cuento, la fantasía y las creencias, Catarroja (Valencia), Perifèric, 2010.
} 
la literatura popular perteneciente al folclore que, de forma anónima, se transmite oralmente entre generaciones como un valor patrimonial precioso y como un producto espiritual, reflejo del sentir de la fantasía, de la magia, de lo cotidiano sumado al elemento maravilloso, como un sustrato ancestral de la mente de todos los pueblos y civilizaciones de la tierra.

Asimismo, la autora marca unos objetivos didácticos muy concretos como trabajar la oralidad en clase, que el alumnado se sienta creador de ideas y comparar el habla de la narrativa oral con el registro de la lengua culta a través de una nutrida selección de etnotextos, recopilados de diversos países con el máximo rigor.

Es muy interesante destacar cómo la profesora Morote señala la vinculación de la Literatura oral al concepto de cultura, puesto que la tradición oral es materia integrada en el acervo cultural de todos los pueblos del mundo, sirviendo de referente a la intertextualidad para la Lingüística y a la interculturalidad para la Etnografía.

El carácter pedagógico del libro se refleja, además, en el concepto y clasificación de la oralidad (en tres tipos: primaria, mixta o coexistente con la escritura y mediatizada en contacto con la tecnología) y en la organización de los subgéneros más diferenciados, registrándose más de veinte modalidades tan curiosas como exóticas (mayos, rogativas, loas, retahílas, trabalenguas, albadas, brindis o gozos de santo).

La autora presta especial atención al género «leyenda», comparándola con otros géneros narrativos como el cuento, el mito o el romance. Entre la clasificación de leyendas resaltan por su originalidad las llamadas de «ritualización del calendario festivo», concepto utilizado por primera vez por la autora.

En los etnotextos se analizan leyendas de España, Estados Unidos, Colombia, Ecuador, Guatemala y Méjico. Destaca un capítulo sobre pautas para trabajar las leyendas en las aulas, con un eminente carácter didáctico.

Hay que mencionar también la sólida base bibliográfica utilizada en el libro, así como las citas de las teorías de los hermanos Grimm, Menéndez Pidal, García de Diego, Caro Baroja, ya clásicos, pero también los actuales Paul Zumthor, Walter Ong y el español José Manuel Pedrosa, personalidad destacada en Literatura Comparada.

A modo de resumen, voy a utilizar un símil: este libro, como un logrado trabajo de investigación, lo comparo con cualquier obra arquitectónica ejemplar. La Arquitectura es ciencia y arte. Es cálculo matemático, medida, proporción, armonía, funcionalidad y belleza en el resultado. El libro que les comento cuenta con estas características: es ciencia en su sólida base teórica, buenos materiales y utilidad y es arte en su forma, en su lenguaje, en su discurso ameno y cercano, a la par que académico, hasta el punto de encontrar gusto en su lectura, que responde al placer de todo trabajo bien hecho, aparte de los conocimientos que contiene, fuente de aprendizaje incuestionable para todo lector. 
Acabo con dos citas literarias y unas palabras de la autora. La primera cita es de Antonio Machado cuando dice: «¿Queréis conocer la historia de un pueblo? Ved sus romances. ¿Aspiráis a saber de lo que es capaz? Estudiad sus cantares». La segunda cita es de Miguel de Unamuno cuando dice: «Es detestable esa avaricia espiritual que tienen los que, sabiendo algo, no procuran la transmisión de esos conocimientos». En este caso, la doctora Morote ha cumplido doblemente: extrayendo toda la sabiduría popular de la literatura oral a través de sus entrevistados y, habiendo estudiado a fondo, analizado y organizado ese valiosísimo material literario y humano, ha sabido transmitirlo generosamente en sus escritos, conferencias y clases a todo el público interesado en esta rama del saber literario: la literatura oral, calificada por la autora como un «pequeño gran tesoro» y añade que el eje temático y estético en los géneros orales es la tierra, la familia y la sociedad cercana al individuo.

Para terminar, diré que el libro Aproximación a la literatura oral de la doctora Morote, por su rigor metodológico, por su estructura, por el interesante material utilizado, por su valor didáctico, por la base bibliográfica manejada, por los resultados presentados y por su indudable utilidad para expertos y aprendices de la literatura oral, es un libro que merece perdurar como manual indispensable de consulta y como un verdadero «tratado» en la materia investigada más que como una «aproximación», como reza modestamente el título. 